\title{
France, America and the Modern, Edited by Jackie Clarke and Carole Sweeney
}

\section{Emanuele Kanceff}

\section{Q OpenEdition \\ 1 Journals}

\section{Edizione digitale}

URL: http://journals.openedition.org/studifrancesi/27932

DOI: 10.4000/studifrancesi.27932

ISSN: 2421-5856

\section{Editore}

Rosenberg \& Sellier

\section{Edizione cartacea}

Data di pubblicazione: 31 décembre 2006

Paginazione: 634

ISSN: 0039-2944

\section{Notizia bibliografica digitale}

Emanuele Kanceff, «France, America and the Modern, Edited by Jackie Clarke and Carole Sweeney », Studi Francesi [Online], 150 (L | III) | 2006, online dal 30 novembre 2015, consultato il 08 novembre 2020. URL : http://journals.openedition.org/studifrancesi/27932 ; DOI : https://doi.org/10.4000/ studifrancesi.27932

\section{Questo documento è stato generato automaticamente il 8 novembre 2020}

\section{(c) (1)}

Studi Francesi è distribuita con Licenza Creative Commons Attribuzione - Non commerciale - Non opere derivate 4.0 Internazionale. 


\title{
France, America and the Modern, Edited by Jackie Clarke and Carole Sweeney
}

\author{
Emanuele Kanceff
}

\section{NOTIZIA}

AA. VV., France, America and the Modern, Edited by Jackie Clarke and Carole Sweeney, «Nottingham French Studies», vol. 44, number 3, Autumn 2005, pp. 99.

1 La nota rivista dedica un numero al problema del moderno e alle sue letture, in un quadro molto vasto in cui la Francia e l'America sono protagoniste. Impossibile seguire nel dettaglio il dipanarsi dei diversi saggi, che formano un insieme molto stimolante, in cui il vento di novità spira fresco come i grandi venti d'America. Ci dovremo limitare a dettagliarne il contenuto per il lettore.

Introduction, di Jackie Clarke e Carole S weeney (p.1) - "Le Sacre du Printemps". Primitivism, Popular Dance, and the Parisian Avant-Garde, di Sarah Kennel (p. 4) - America the Specular: Seeing an Americanism in "Parade" and "La Création du monde", di Charles BATson (p. 24) - Jazz as "Habitus": Discourse of Class and Ethnicity in Hugues Panassiés "Le Jazz Hot" (1934), di Jeremy F. LANE (p.40) - Tourists or Exiles? American Modemists in Paris in the 1920s and 1950s, di Martin HaLliwell (p. 54) - "Tel Quel" in Manhattan: America and the French Avant-Garde, 1960-82, di Peter BUSE (p. 69) - The Time of the Modem: From Paris to New York, di Paul HegarTy (p. 83) - Afterword, di Kristin Ross (p. 94).

Delle utili "Notes on Contributors" concludono l'interessante e variegato numero unico. 